\title{
EFFECTS OF BICARBONATE REMOVAL ON THE SPONTANEOUS MECHANICAL ACTIVITY OF THE GUINEA PIG UTERUS
}

\author{
Takashi KATASE \\ Department of Physiology, Faculty of Medicine, \\ Kyushu University, Fukuoka 812, Japan
}

\begin{abstract}
Summary 1. Effects of bicarbonate removal and of decreasing external $\mathrm{pH}$ on the mechanical and electrical activities in isolated strips of the guinea pig uterus were investigated.

2. When bicarbonate was reduced at $37^{\circ} \mathrm{C}$, a high degree of contractile activity was observed, which was associated with high frequency spike activity. However, when the same experiment was repeated at $21^{\circ} \mathrm{C}$, the activity was suppressed. These sustained contractions were produced whether the $\mathrm{HCO}_{3}^{-}$-free solution was acid ( $\mathrm{pH}$ : about 6) in the presence of $3 \% \mathrm{CO}_{2}$, or the solution was alkaline $(\mathrm{pH}$ : about 8$)$ in the absence of $\mathrm{CO}_{2}$.

3. When the $\mathrm{pH}$ of the solution was decreased to 6 by $5 \mathrm{~mm}$ tris malate buffer, the mechanical activity was also increased in the presence of $15.5 \mathrm{mM} \mathrm{HCO}_{3}^{-}$.

4. In low $\mathrm{Cl}^{-}(7 \mathrm{~mm}) \mathrm{Krebs}$ solution the mechanical activity depended on the substitute for $\mathrm{Cl}^{-}$: substitution with isethionate reduced or stopped the activity, while substitution with $\mathrm{NO}_{3}^{-}$increased the activity. The increase in activity on $\mathrm{HCO}_{3}^{-}$removal was less in isethionate solution and much larger in $\mathrm{NO}_{3}^{-}$solution.

5. At a lower temperature $\left(21^{\circ} \mathrm{C}\right), \mathrm{HCO}_{3}^{-}$removal suppressed the activity when $\mathrm{O}_{2}$ containing $3 \% \mathrm{CO}_{2}$ was bubbled through the solution.

6. It is suggested that $\mathrm{HCO}_{3}^{-}$removal and acidification increase $\mathrm{Cl}^{-}$ permeability of the membrane and that this leads to high spontaneous activity. It is also possible that modification of the external buffer system may affect the internal $\mathrm{pH}$ and metabolism, which in turn modifies spontaneous activity.
\end{abstract}

The smooth muscle of the guinea pig uterus has spontaneous activity, but the pattern of activity varies greatly from preparation to preparation. The ex-

Received for publication May 30, 1974

片瀬 高 
planation for this is unknown and, indeed, little information is available about factors which control spontaneous activity.

In the guinea pig taenia coli, replacement of $\mathrm{Cl}^{-}$with a less permeant anion usually suppresses the spontaneous electrical activity, whereas replacement of $\mathrm{Cl}^{-}$with a more permeant anion accelerates the spontaneous activity (KURIYAMA, 1963; BülBRING and TOMITA, 1969). This suggests a possibility that the pacemaker potential is due to movements of $\mathrm{Cl}^{-}$ions in normal solution. It is known that foreign anions decrease the $\mathrm{Cl}^{-}$permeability of the membrane in the frog skeletal muscle (HutTER and PADSHA, 1959). Since a physiological Krebs solution contains between 15 and $25 \mathrm{mM} \mathrm{NaHCO}_{3}$ as a buffer (BÜLBRING, 1953; Goodford and Hermansen, 1961; Krebs, 1950; Krebs and Henseleit, 1932), $\mathrm{HCO}_{3}^{-}$ions may affect the $\mathrm{Cl}^{-}$permeability. Therefore, in the present experiments, effects of $\mathrm{HCO}_{3}^{-}$removal were studied on the isolated strip of the guinea pig uterus. It was found that a reduction of the external $\mathrm{HCO}_{3}^{-}$concentration increases the spontaneous activity, as would be expected from changes in the $\mathrm{Cl}^{-}$ permeability.

\section{METHODS}

Guinea pigs weighing $250-330 \mathrm{~g}$ were stunned and bled. The uterus was quickly removed, and strips of uterus ( $20 \mathrm{~mm}$ long, 1-2 mm wide) were dissected. The strips were suspended in an organ bath $(20 \mathrm{ml}$ capacity) and connected to a strain gauge transducer to record mechanical activity isometrically.

The control Krebs solution contained $\mathrm{NaCl} 121 \mathrm{mM}$, glucose $11.5 \mathrm{~mm}, \mathrm{CaCl}_{2}$ $2.5 \mathrm{~mm}, \mathrm{NaHCO}_{3} 15.5 \mathrm{~mm}, \mathrm{MgCl}_{2} 1.2 \mathrm{~mm}$, and $\mathrm{KCl} 5.9 \mathrm{~mm}$. A gas mixture composed of $3 \% \mathrm{CO}_{2}$ and $97 \% \mathrm{O}_{2}$ was bubbled through the solution. When $\mathrm{NaHCO}_{3}$ was reduced, it was replaced with an equimolar concentration of $\mathrm{NaCl}$. In some experiments, pure $\mathrm{O}_{2}$ was bubbled through the solution.

Solutions flowed continuously through the organ bath at a constant speed of about $2 \mathrm{ml} / \mathrm{min}$, and it took about $30 \mathrm{~min}$ for a complete change of the solution. The effects of $\mathrm{CO}_{2}$ bubbling on the $\mathrm{pH}$ of the external solution were much faster than those of $\mathrm{HCO}_{3}^{-}$removal because of the slow speed of changing the solution. The $\mathrm{pH}$ of the perfused solutions was measured by placing a $\mathrm{pH}$ electrode near the preparation in the organ bath. The electrical outputs of $\mathrm{pH}$ meter (Toa Electronics, Model HM-6A) and of the strain gauge transducer were simultaneously recorded on a potentiometric pen recorder (National Electronics Model VP652B).

At least three preparations from different animals were used in each experiment. Occasionally a pregnant uterus was used but since the responses were not different from those obtained in uteri from non-pregnant animals, the hormonal stage of the uterus was not considered.

In some experiments, electrical recordings were made under the same experimental condition as in mechanical recordings. External electrodes (Ag- 
$\mathrm{AgCl}, 100 \mu$ in diameter) were placed across the preparation.

\section{RESULTS}

Effects of removal of $\mathrm{HCO}_{3}^{-}$

The smooth muscle of the guinea pig uterus contracts spontaneously. The pattern of the spontaneous activity was irregular and varied in different preparations. It usually appeared as a burst which occurred every few minutes. Experiments were started after equilibrating the tissue in the organ bath for at least $30 \mathrm{~min}$.

Figure 1 shows an example of the mechanical response produced by removal of $\mathrm{HCO}_{3}^{-}$from the Krebs solution. When the $\mathrm{HCO}_{3}^{-}$concentration was reduced from $15.5 \mathrm{~mm}$ to $0 \mathrm{~mm}$, the $\mathrm{pH}$ of the external solution declined from 7.5 to about 6 in the presence of $3 \% \mathrm{CO}_{2}$. The duration of a burst of spontaneous contractions was prolonged and tension was maintained at a high level during the exposure to the $\mathrm{HCO}_{3}^{-}$deficient solution. There were many small contractions superimposed on the sustained tension. The normal pattern of activity reappeared on returning the $\mathrm{HCO}_{3}^{-}$concentration to normal $(15.5 \mathrm{~mm})$, but it took about $10 \mathrm{~min}$ before the first burst of activity started.
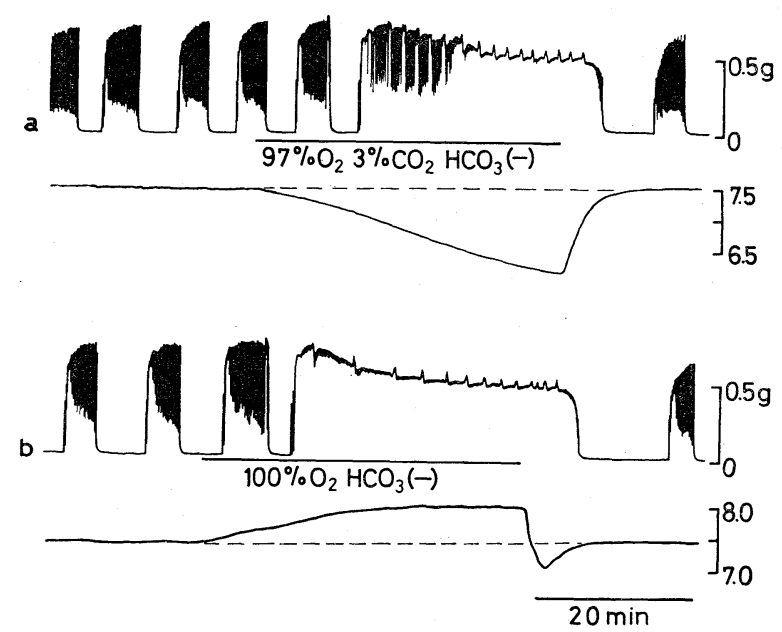

Fig. 1. Effects of $\mathrm{HCO}_{3}^{-}$removal on mechanical activity (top) and $\mathrm{pH}$ of the external solution (bottom) of guinea pig uterine smooth muscle. Flow of $\mathrm{HCO}_{3}^{-}$-free solution is indicated by the horizontal bar. a: a gas mixture of $3 \% \mathrm{CO}_{2}$ and $97 \% \mathrm{O}_{2}$ was bubbled through the solution. b: $3 \% \mathrm{CO}_{2}$ and $97 \% \mathrm{O}_{2}$ was changed to $100 \% \mathrm{O}_{2}$ during the flow of $\mathrm{HCO}_{3}^{-}$free solution.

When the reduction of the $\mathrm{HCO}_{3}^{-}$concentration was accompanied by a change in the composition of the gas from $3 \% \mathrm{CO}_{2}$ and $97 \% \mathrm{O}_{2}$ to $100 \% \mathrm{O}_{2}$, the $\mathrm{pH}$ of the external solution increased from 7.5 to about 8 (Fig. 1b). Although 
the $\mathrm{pH}$ of the solution was different, the mechanical response produced by $\mathrm{HCO}_{3}^{-}$ reduction was essentially the same as when $3 \% \mathrm{CO}_{2}$ was used throughout the experiment. The increase in activity produced by $\mathrm{HCO}_{3}^{-}$removal was stronger when the resting tension of the preparation was increased by stretching.

Small contractions during periods of high maintained tension in $\mathrm{HCO}_{3}^{-}$-free solution suggest the presence of spike activity. As shown in Fig. 2, there was a good correlation between the tension development (upper trace) and the spike activity (lower trace).
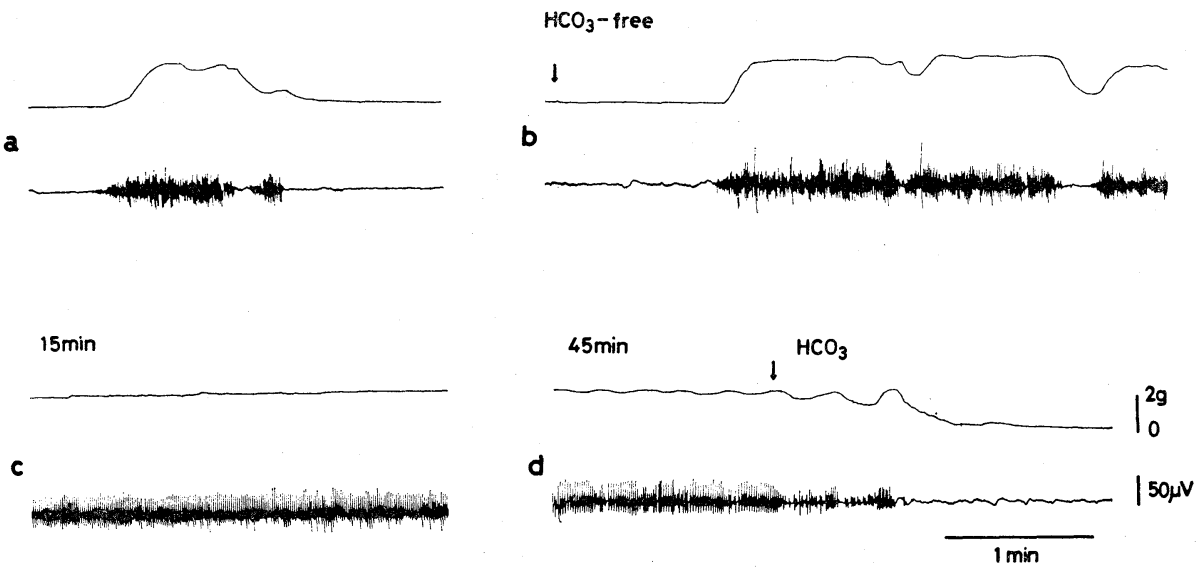

Fig. 2. Effects of $\mathrm{HCO}_{3}^{-}$removal on mechanical (top) and electrical (bottom) activities. Note the good correlation between tension development and spike activity in normal solution (a) and also in $\mathrm{HCO}_{3}^{-}$-free solution (b, c \& d).

\section{Tris buffer experiments}

The $\mathrm{pH}$ of the external solution was reduced to less than 6.5 by removing $\mathrm{HCO}_{3}^{-}$. To examine the effect of lowering external $\mathrm{pH}$, solutions containing $5 \mathrm{~mm}$ tris malate buffer with a given $\mathrm{pH}$ in place of an equivalent amount of $\mathrm{NaCl}$ were used. Pure $\mathrm{O}_{2}$ was bubbled through the solution. The $\mathrm{pH}$ of the control solution which contained $15.5 \mathrm{mM} \mathrm{HCO}_{3}^{-}$and $5 \mathrm{~mm}$ tris malate was 8.2. A slight increase in the activity was observed (Fig. 3a). This suggests that the tris buffer has some excitatory action.

When the $\mathrm{pH}$ was lowered to 6.0 by adjusting with tris malate buffer in the presence of normal concentration of $\mathrm{HCO}_{3}^{-}$, the activity was strongly increased (Fig. 3b). Similar results were obtained in four other preparations at a $\mathrm{pH}$ between 6 and 6.5. When $\mathrm{HCO}_{3}^{-}$was removed, the sustained activity was always produced regardless of the external $\mathrm{pH}$.

\section{Effects of $\mathrm{HCO}_{3}^{-}$removal in $\mathrm{Cl}^{-}$-deficient solution}

It is possible that removal of $\mathrm{HCO}_{3}^{-}$increases the $\mathrm{Cl}^{-}$permeability of the membrane, and that the mechanical response produced by reducing the $\mathrm{HCO}_{3}^{-}$ 

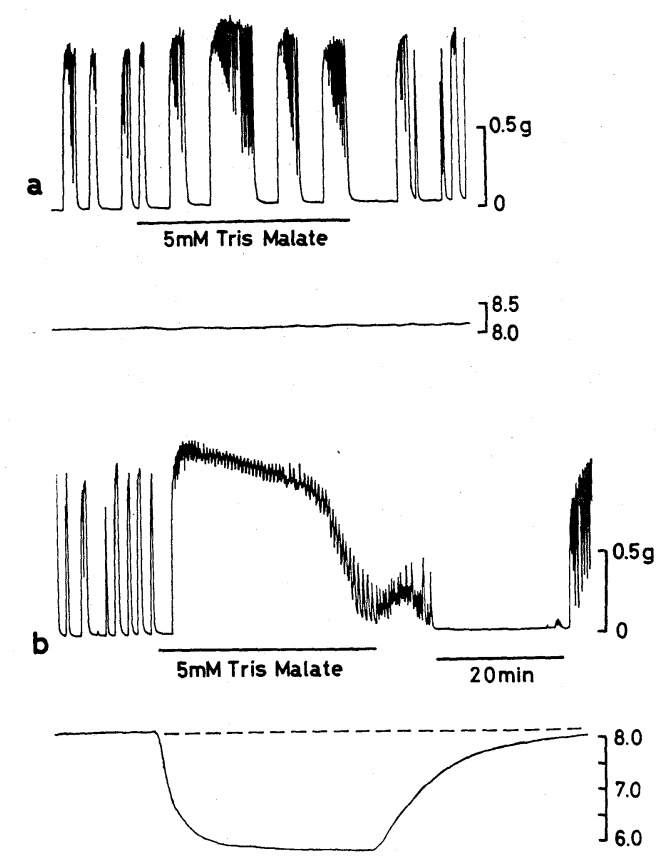

Fig. 3. Effects of $\mathrm{pH}$ adjustment by tris malate $(5 \mathrm{~mm})$ buffer in the presence of $15.5 \mathrm{~mm}$ $\mathrm{HCO}_{3}^{-}$. $\quad 100 \% \mathrm{O}_{2}$ was bubbled throughout. a: $\mathrm{pH}$ was kept constant at 8.2. b: $\mathrm{pH}$ was changed from 8.2 to 5.9. Horizontal bars indicate flow of the solution containing $5 \mathrm{~mm}$ tris malate with a given $\mathrm{pH}(8.2$ in (a) and 5.9 in (b)).
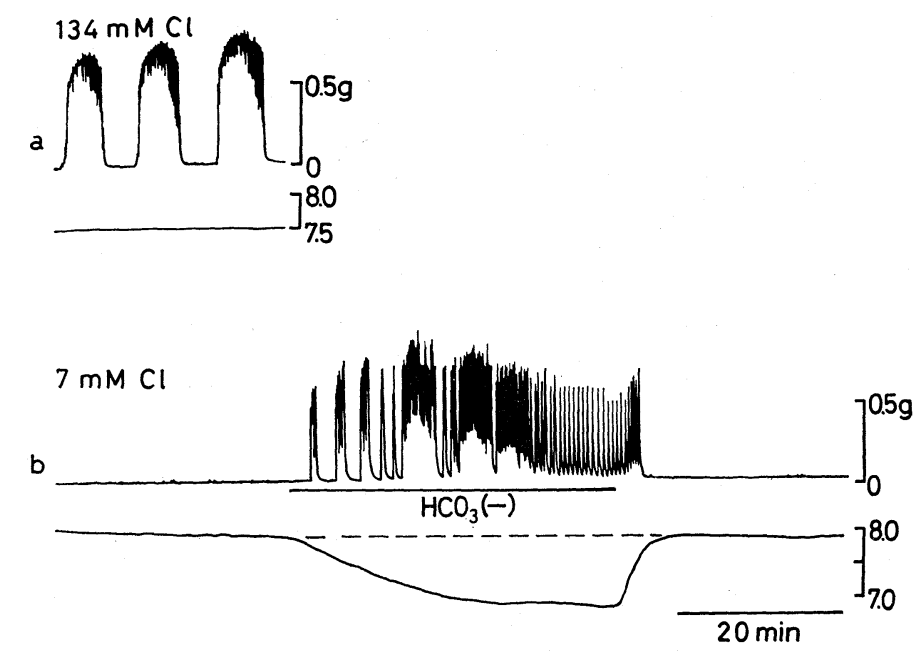

Fig. 4. Effects of $\mathrm{HCO}_{3}^{-}$removal in $\mathrm{Cl}^{-}$-deficient isethionate solution $\left(7 \mathrm{mM} \mathrm{Cl}^{-}\right)$. a: mechanical activity in normal solution. b: after $30 \mathrm{~min}$ in isethionate solution, and when $\mathrm{HCO}_{3}^{-}$was removed from the solution (horizontal bar). The $\mathrm{pH}$ of the isethional solution was 7.8 . 
concentration is somehow mediated through the change in the $\mathrm{Cl}^{-}$permeability. Lowering the $\mathrm{pH}$ of the external solution may also affect the $\mathrm{Cl}^{-}$permeability, since it has been reported that $\mathrm{pH}$ influences the $\mathrm{Cl}^{-}$permeability of the membrane in frog skeletal muscle (HUTTER and WARNER, 1967), barnacle muscle (HAGIwARA et al., 1968) and cardiac muscle (CARMELIET and BosteEls, 1969).

When $\mathrm{NaCl}$ and $\mathrm{KCl}$ in $\mathrm{Krebs}$ solution were replaced with an equimolar concentration of isethionate salts, leaving $7 \mathrm{mM} \mathrm{Cl}^{-}$as $\mathrm{CaCl}_{2}$ and $\mathrm{MgCl}_{2}$, the activity was suppressed after a period of about 20 min during which irregular bursts of high activity appeared. Activity was again produced by removing $\mathrm{HCO}_{3}^{-}$, but the tension was not maintained as in the normal solution containing $\mathrm{Cl}^{-}$ (Fig. 4). In three other preparations similar results were obtained. In two preparations, some spontaneous activity remained in the $\mathrm{Cl}^{-}$-deficient solution, but its frequency was much slower than in normal Krebs solution.

In contrast to isethionate, substitution of $\mathrm{Cl}^{-}$with $\mathrm{NO}_{3}^{-}$increased the spontaneous activity. Removal of $\mathrm{HCO}_{3}^{-}$from the $\mathrm{Cl}^{-}$-deficient $\mathrm{NO}_{3}^{-}$solution further increased the activity so that a strong sustained contraction was produced (Fig. 5).
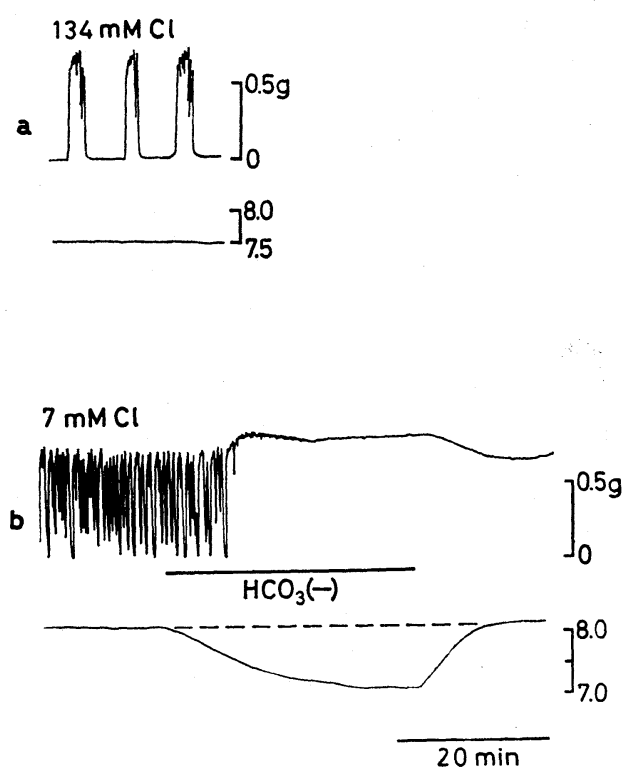

Fig. 5. Effects of $\mathrm{HCO}_{3}^{-}$removal in $\mathrm{Cl}^{-}$-deficient $\mathrm{NO}_{3}^{-}$solution $\left(7 \mathrm{mM} \mathrm{Cl}^{-}\right)$. a: $\mathrm{Me}$ chanical activity in normal solution. b: After $30 \mathrm{~min}$ in $\mathrm{NO}_{3}^{-}$solution, $\mathrm{HCO}_{3}^{-}$was removed (horizontal bar).

\section{Effects of temperature}

It may be that removal of $\mathrm{HCO}_{3}^{-}$reduces the intracellular $\mathrm{pH}$ and that the spontaneous activity is produced as a result of a change in cell metabolism following the $\mathrm{pH}$ change. If this is true, a large effect of temperature would be expected. 
Figure 6 shows the effect of a removal of $\mathrm{HCO}_{3}^{-}$at two different temperatures. At $37^{\circ} \mathrm{C}$ (a), a sustained increase in tension was produced by removing $\mathrm{HCO}_{3}^{-}$. This response was essentially the same as that shown in Fig. 1a. However, when the same experiment was repeated at $21^{\circ} \mathrm{C}(\mathrm{b})$, the removal of $\mathrm{HCO}_{3}^{-}$suppressed the activity. The activity quickly reappeared on admission of $15.5 \mathrm{mM} \mathrm{HCO}_{3}^{-}$. Thus, lowering the temperature reversed the effect of $\mathrm{HCO}_{3}^{-}$-free solution.
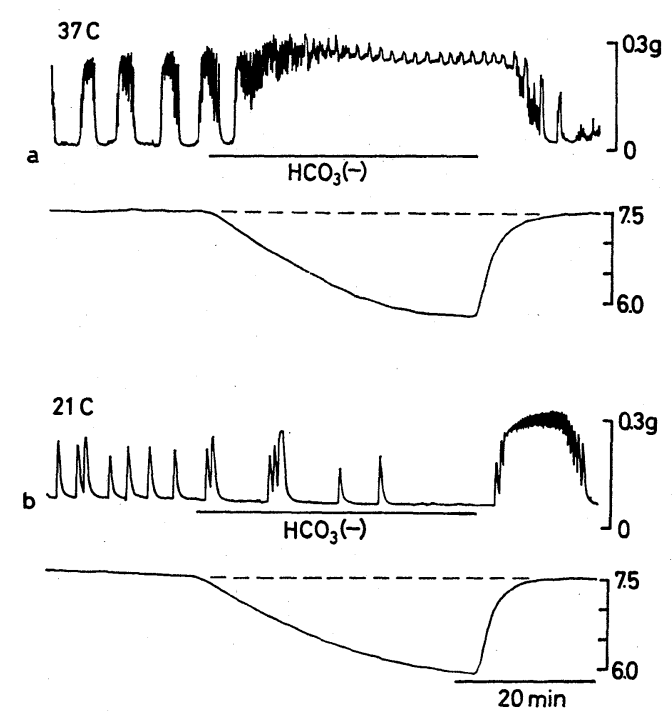

Fig. 6. Effects of $\mathrm{HCO}_{3}^{-}$removal at $37^{\circ} \mathrm{C}$ (a) and $21^{\circ} \mathrm{C}$ (b). After recording the response (a) at $37^{\circ} \mathrm{C}$ the organ bath was cooled down to $21^{\circ} \mathrm{C}$ and equilibrated at this temperature for 30 min before taking record (b).

The activity was increased when the $\mathrm{pH}$ was lowered to $6-6.5$ by tris malate buffer (Fig. 3b and Fig. 7a). In this experiment, the initially applied solution contained $15.5 \mathrm{mM} \mathrm{HCO}_{3}^{-}$and was bubbled with $100 \% \mathrm{O}_{2}$. The excitatory effect of the tris malate buffer was not essentially modified by lowering the temperature from $37^{\circ} \mathrm{C}$ to $21^{\circ} \mathrm{C}$ (Fig. $7 \mathrm{~b}$ ). Thus, at $37^{\circ} \mathrm{C}$ the effect of $\mathrm{HCO}_{3}^{-}$removal was the same as that of acidification with tris malate buffer, while at $21^{\circ} \mathrm{C}$ their effects were different.

The absence of suppression by acidification with tris buffer at the lower temperature could be related either to the presence of $\mathrm{HCO}_{3}^{-}$or to the absence of $\mathrm{CO}_{2}$. In order to discriminate between these possibilities, the following experiments were carried out.

The $\mathrm{pH}$ of the solution was about 8.2 since pure oxygen was used instead of $3 \% \mathrm{CO}_{2}$ and $97 \% \mathrm{O}_{2}$. At $37^{\circ} \mathrm{C}$ removal of $\mathrm{HCO}_{3}^{-}$increased the activity, although the $\mathrm{pH}$ did not fall much below 8.0. This is in accord with the result shown in Fig. 1b. Suppression of activity by removal of $\mathrm{HCO}_{3}^{-}$was very weak or 

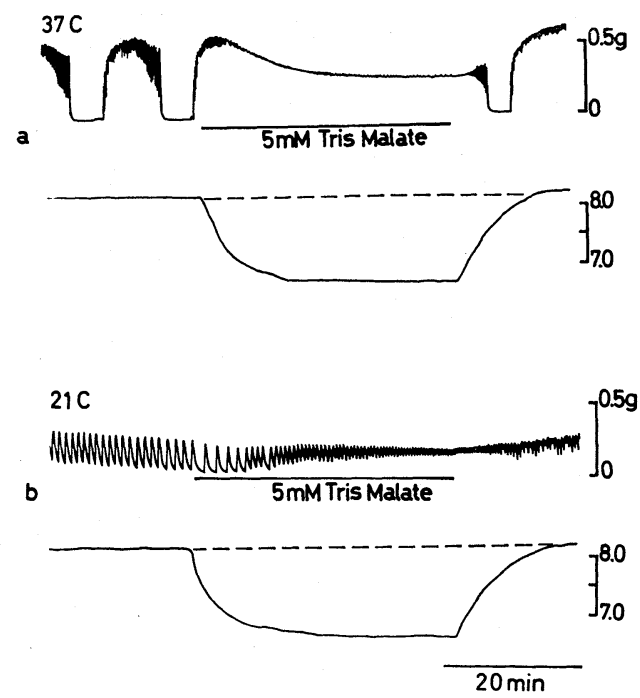

Fig. 7. Effects of acidification (pH: 6.7) at $37^{\circ} \mathrm{C}$ (a) and $21^{\circ} \mathrm{C} \mathrm{(b).} \mathrm{pH} \mathrm{was} \mathrm{adjusted} \mathrm{with}$ $5 \mathrm{~mm}$ tris malate buffer (horizontal bar). $100 \% \mathrm{O}_{2}$ was bubbled throughout.

absent at $21^{\circ} \mathrm{C}$, and a transient suppression appeared on readmission of $15.5 \mathrm{~mm}$ $\mathrm{HCO}_{3}^{-}$(Fig. 8b). In the $\mathrm{HCO}_{3}^{-}$-free solution, the activity was inhibited by bubbling $3 \% \mathrm{CO}_{2}$ at $21^{\circ} \mathrm{C}$ (Fig. $8 \mathrm{c}$ ), as expected from the result shown in Fig. $6 \mathrm{~b}$, and an increase in activity quickly appeared when $\mathrm{CO}_{2}$ supply was stopped.

\section{DISCUSSION}

Removal of $\mathrm{HCO}_{3}^{-}$produces sustained increase in tension due to a high spontaneous spike activity in the smooth muscle of the guinea pig uterus. Acidification of the external solution is not an essential factor for this response, since the sustained tension is also produced by $\mathrm{HCO}_{3}^{-}$removal at $\mathrm{pH} 8.0$ when $3 \% \mathrm{CO}_{2}$ is omitted (Fig. 1b and Fig. 8a). Acidification may be an additional factor increasing the activity. This is suggested by the sustained high mechanical activity observed in the presence of $15.5 \mathrm{mM} \mathrm{HCO}_{3}^{-}$when the $\mathrm{pH}$ is adjusted to 6.0 by tris malate buffer.

High spontaneous activity produced by $\mathrm{HCO}_{3}^{-}$removal or by acidification may be a result of an increase in $\mathrm{Cl}^{-}$permeability. Substitution of $\mathrm{Cl}^{-}$with a large anion, isethionate, reduces or stops the spontaneous activity. On the other hand, substitution of $\mathrm{Cl}^{-}$with $\mathrm{NO}_{3}^{-}$, which is probably more permeant, increases the activity. In the smooth muscle of the guinea pig taenia coli, the high permeability of $\mathrm{NO}_{3}^{-}$compared with $\mathrm{Cl}^{-}$has been demonstrated by measurements of volume changes produced by osmotic pressure (BRADING and ToMITA, 1968). Thus, it seems that the anion permeability controls, in some way, the generation of spontaneous activity. For example, an increase in anion permeabi- 

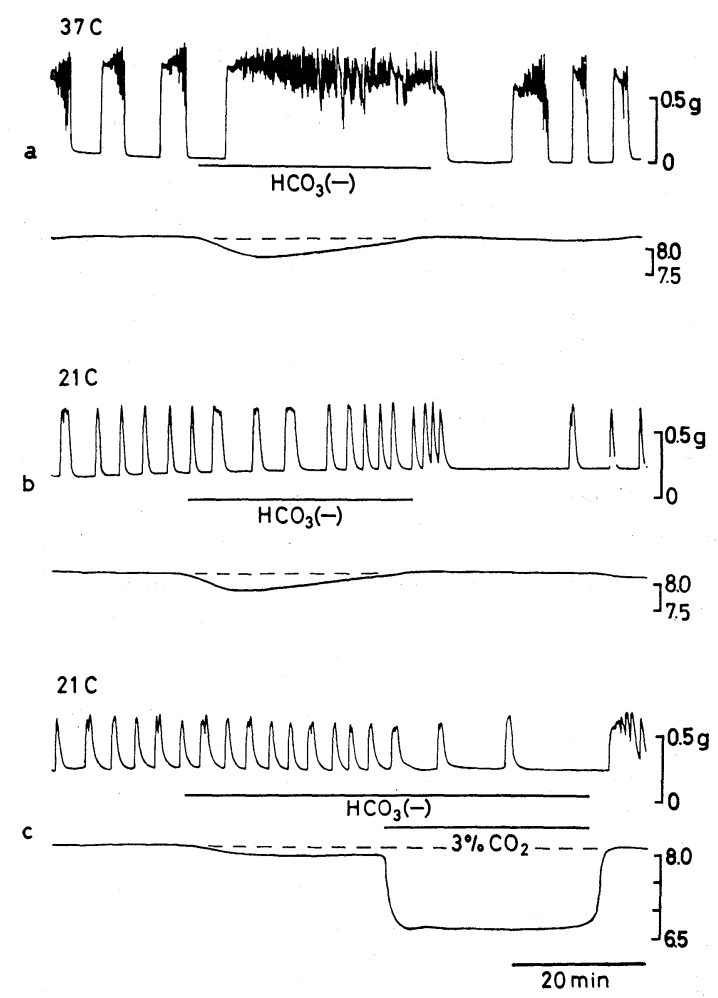

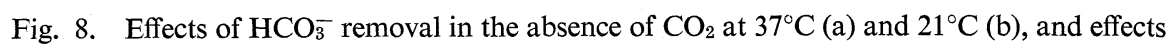
of $3 \% \mathrm{CO}_{2}$ in the absence of $\mathrm{HCO}_{3}^{-}$at $21^{\circ} \mathrm{C} \mathrm{(c)}$.

lity may contribute to the depolarization of the pacemaker potential, as proposed for cardiac muscle (HUTTER and NOBLE, 1961).

It has been suggested that foreign anions suppress the $\mathrm{Cl}^{-}$permeability in the frog striated muscle, probably due to some interaction with the anion channels (Hutter and PAdsha, 1959). It is possible that $\mathrm{HCO}_{3}^{-}$acts in this way also in smooth muscle and that removal of $\mathrm{HCO}_{3}^{-}$increases the $\mathrm{Cl}^{-}$permeability.

In the frog skeletal muscle the $\mathrm{Cl}^{-}$permeability decreases with decreasing the external pH (HUTTER and WARNER, 1967). In contrast, the $\mathrm{Cl}^{-}$permeability increases with decreasing the external $\mathrm{pH}$ in crustacean muscle fibers (DE MELLO and Hutter, 1966; Hagiwara et al., 1968; Reuben et al., 1962). In the guinea pig taenia coli, a recovery of tissue weight in hypertonic solution made by adding $\mathrm{KCl}$ or $\mathrm{KNO}_{3}$ is accelerated by acidification (M. Ohba and T. Tomita, personal communication), suggesting an increase in anion permeability with decreasing $\mathrm{pH}$, as in the crustacean muscle. This property may also be applicable to the uterine smooth muscle. Then, it is reasonable to assume that an increase in the $\mathrm{Cl}^{-}$permeability is at least partly responsible for the high activity in the $\mathrm{HCO}_{3}^{-}$- 
free and acid solutions.

The excitatory effect of $\mathrm{HCO}_{3}^{-}$removal is reversed to an inhibitory effect when the temperature is lowered to $21^{\circ} \mathrm{C}$. The presence of $\mathrm{CO}_{2}$ seems necessary for this suppression. However, it is difficult to elucidate the mechanism of the $\mathrm{HCO}_{3}^{-}$effect on spontaneous activity at different temperatures. It is possible that intracellular $\mathrm{Cl}^{-}$concentration is reduced at low temperature shifting the equilibrium potential for $\mathrm{Cl}^{-}$to a more negative level than the resting potential, and that the contribution of $\mathrm{Cl}^{-}$conductance increase on $\mathrm{HCO}_{3}^{-}$removal to the membrane potential is reversed. It is also possible that changes in intracellular pH may affect the cellular metabolism which regulates in a complicated way the spontaneous activity. For example, it is reported that in the frog skeletal muscle, glucose-6-phosphate increases, and creatinephosphate and the efflux of lactate decrease on reducing the external $\mathrm{HCO}_{3}^{-}$concentration (MAINwood et al., 1972). These biochemical changes may also occur in the uterine smooth muscle and may affect the membrane properties.

I would like to thank Professor T. Tomita for his advice in this study. I am also grateful to Professor N. Toida and Professor I. Taki for their hospitality and encouragement, and to Dr. Alison F. Brading, Oxford, for improving the manuscript.

\section{REFERENCES}

Brading, A. F. and Tomita, T. (1968) Effect of anions on the volume of smooth muscle. Nature, Lond., 218: 276-277.

Bülbring, E. (1953) Measurements of oxygen consumption in smooth muscle. J. Physiol., 122: 111-134.

BülbRING, E. and Tomita, T. (1969) Increase of membrane conductance by adrenaline in the smooth muscle of guinea-pig taenia coli. Proc. R. Soc. B., 172: 89-102.

Carmeliet, E. and Bosteels, S. (1969) Coupling between $\mathrm{Cl}$ flux and $\mathrm{Na}$ or $\mathrm{K}$ flux in cardiac Purkinje fibers. Influence of pH. Arch. Int. Physiol., Biochim., 77: 57-72.

De Mello, W. and Hutter, O. F. (1966) The anion conductance of crustacean muscle. $J$. Physiol., 183: 11-13 P.

Goodford, P. J. and Hermansen, K. (1961) Sodium and potassium movements in the unstriated muscle of the guinea-pig taenia coli. J. Physiol., 158: 426-448.

Hagiwara, S., Gruener, R., Hayashi, H., Sakata, H., and Grinnell, A. D. (1968) Effect of external and internal $\mathrm{pH}$ changes on $\mathrm{K}$ and $\mathrm{Cl}$ conductances in the muscle fiber membrane of a giant barnacle. J. gen. Physiol., 52: 773-792.

Hutter, O. F. and Noble, D. (1961) Anion conductance of cardiac muscle. J. Physiol., 157: 335-350.

Hutter, O. F. and Padsha, S. M. (1959) Effect of nitrate and other anions on the membrane resistance of frog skeletal muscle. J. Physiol., 146: 117-132.

Hutter, O. F. and Warner, A. E. (1967) The pH sensitivity of the chloride conductance of frog skeletal muscle. J. Physiol., 189: 403-425.

KreBs, H. A. (1950) Body size and tissue respiration. Biochim Biophys. Acta, 4: 249-269.

Krebs, H. A. and Henseleit, K. (1932) Untersuchungen über die Harnstoffbildung im Tierörper. Hoppe-Seyler's Physiol., Chem., 210: 33-66.

KuRIYAMA, H. (1963) The influence of potassium, sodium and chloride on the membrane po- 
tential of the smooth muscle of taenia coli. J. Physiol., 166: 15-28.

Mainwood, G. W., Worsley-Brown, P., and Paterson, R. A. (1972) The metabolic changes in frog sartorius muscles during recovery from fatigue at different external bicarbonate concentrations. Can. J. Physiol., Pharmacol., 50: 143-155.

ReUben, J. R., GiRARDIER, J., and GRUNDFEST, H. (1962) The chloride permeability of crayfish muscle fibers. Biol. Bull., 123: 509-510. 